\title{
PSEUDO-SENSATION ON THE INTERNET: EXPERIENCE OF LINGUISTIC DESCRIPTION
}

\author{
Andrej A. Negryshev \\ Vladimir State University named after Alexander and Nikolay Stoletovs, Vladimir, Russia
}

\begin{abstract}
The author attempts to consider linguistically the phenomenon of pseudo-sensation which is widespread on the Internet. From the point of view of linguistics pseudo-sensation is a short message of a shocking and provocative nature, constructed on the basis of any media text that does not contain sensational information. Being derived from the source-text, pseudo-sensation differs from a fake, which is a completely fictional message or graphic object. Pseudo-sensational messages are presented on the Internet mainly in the form of announcement headlines. Such headlines function autonomously on a web page as signals motivating to follow a hyperlink. The logical and semantic transformations, employed in pseudo-sensational headlines construction, allow to transform almost any media text into a pseudo-sensation. The description of the mechanisms of such constructing makes the subject of this article. The description is methodologically based upon the "semiotics of truth perversion" by Yu.I. Levin. The analysis of research material, collected from Russian Internet sites, has enabled to reveal three basic logical and semantic transformations: elimination (excluding of one or more components of the text proposition from the headline), substitution (the replacement of the significant components of the text proposition) and complication (addition of excessive components into the headline that are not explicitly contained in the text). The cognitive basis of encouraging to the hypertext transition is the false activation of certain components of the recipient's thesaurus.
\end{abstract}

Key words: pseudo-sensation, media text, Internet headline, logical and semantic transformation, thesaurus.

Citation. Negryshev A.A. Pseudo-Sensation on the Internet: Experience of Linguistic Description. Vestnik Volgogradskogo gosudarstvennogo universiteta. Seriya 2. Yazykoznanie [Science Journal of Volgograd State University. Linguistics], 2020, vol. 19, no. 2, pp. 43-53. (in Russian). DOI: https://doi.org/10.15688/jvolsu2.2020.2.4

\section{ПСЕВДОСЕНСАЦИЯ В ИНТЕРНЕТЕ: ОПЫТ ЛИНГВИСТИЧЕСКОГО ОПИСАНИЯ}

\author{
Андрей Александрович Негрышев \\ Владимирский государственный университет им. А.Г. и Н.Г. Столетовых, г. Владимир, Россия
}

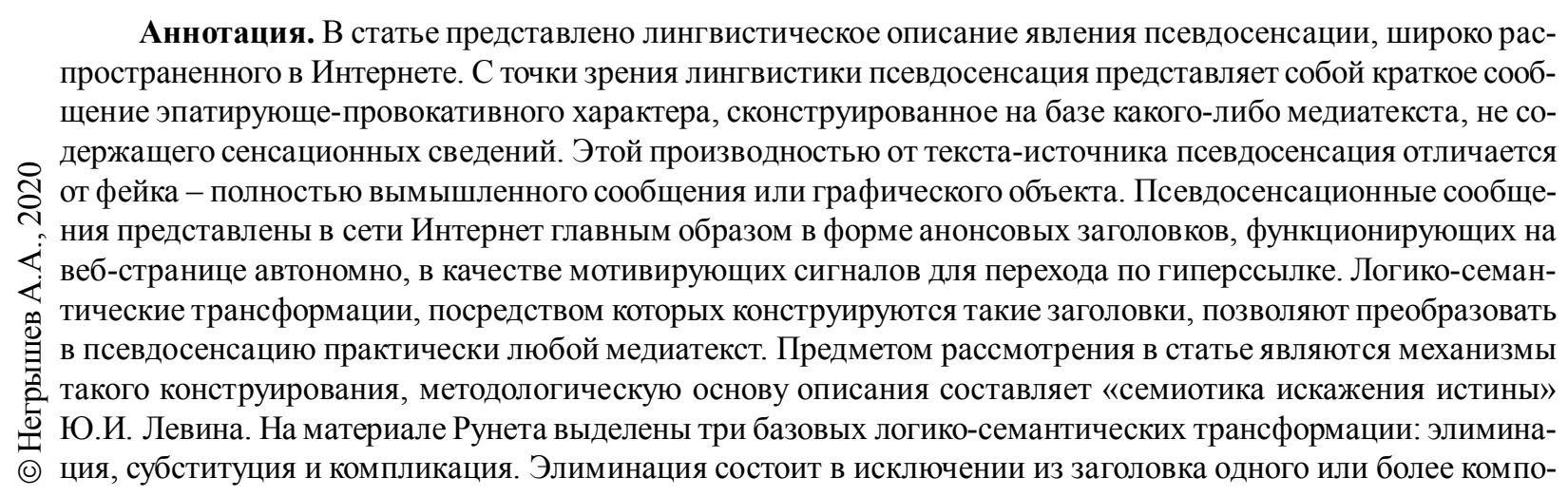




\section{РАЗВИТИЕ И ФУНКЦИОНИРОВАНИЕ РУССКОГО ЯЗЫКА}

нентов текстовой пропозиции, субституция - в подмене значимых компонентов текстовой пропозиции, компликация - во введении в заголовок избыточных компонентов, не содержащихся эксплицитно в тексте. Когнитивную основу побуждения к гипертекстовому переходу составляет ложная активация определенных компонентов тезауруса реципиента.

Ключевые слова: псевдосенсация, медиатекст, интернет-заголовок, логико-семантическая трансформация, тезаурус.

Цитирование. Негрышев А. А. Псевдосенсация в Интернете: опыт лингвистического описания // Вестник Волгоградского государственного университета. Серия 2, Языкознание. - 2020. - Т. 19, № 2. - С. 43-53. DOI: https://doi.org/10.15688/jvolsu2.2020.2.4

\section{Введение}

Понятие сенсации сегодня прочно ассоциируется со сферой массовой коммуникации и СМИ. В толковых словарях это слово определяется как «1. Сильное, волнующее всех впечатление от какого-н. события, известия. 2. Сообщение или событие, производящее такое впечатление, шумиха» (Ушаков, с. 619). Нетрудно заметить, что в этих двух значениях заключено, по сути, три понимания сенсации: 1) сенсация как «впечатление» (новость вызвала сенсаиию, новый роман стал сенсацией, СМИ раздувают сенсачию и т. п.); 2) сенсация как «событие» (встреча президентов стала сенсацией, результаты матча стали сенсацией, в погоне за сенсациями и т. п.); 3) сенсация как «сообщение» (газетная сенсация, свежий номер богат сенсациями, сенсация первой полосы и т. п.). Очевидная взаимообусловленность всех трех значений (впечатление невозможно без события / сообщения, сообщение / впечатление предполагает событие, а событие не произведет «сенсационного» впечатления без сообщения о нем) не препятствует их дифференциации в качестве объектов исследования разных научных дисциплин. Так, «сенсациявпечатление» относится главным образом к области социальной психологии, «сенсациясобытие» - к теории журналистики, а «сенсация-сообщение» - к медиалингвистике, в свою очередь пересекающейся с теорией журналистского творчества.

Если говорить о понимании сенсации как события, то следует отметить, что в теории журналистики общепризнанной является типология сенсаций А.А. Тертычного, выделяющего естественные и искусственные сенсации. И те и другие - это именно события, а не сообщения, различающиеся только тем, что «искусственные» события, в отличие от естественных, имеют постановочный характер (пиар-акции, массовые шоу и т. п.) [Тертычный, 2003]. Для описания сенсации как сообщения наиболее удачной представляется классификация Е.А. Сазонова, выделившего для «желтой прессы» три группы сенсаций: реальные сенсации, квазисенсации и ложные сенсации [Сазонов, 2004, с. 9]. Реальные сенсации имеют референтную основу в виде действительно произошедшего события (естественного либо искусственного по А.А. Тертычному), ложные такой основы не имеют, а квазисенсации возникают «в ходе определенной обработки фактов реальной действительности» [Сазонов, 2004, с. 14]. Если ложные сенсации, традиционно именовавшиеся «утками» или «дутыми фактами», в настоящее время прочно вошли в структуру понятия «фейк» (см., например: [Ильченко, 2018; Иссерс, 2014]), то понятие квазисенсации четкой дефиниции пока не получило.

Между тем именно этот тип сенсаций наиболее доступен для лингвистического описания как в плане эмпирического материала, так и с точки зрения методологии. Современное интернет-пространство изобилует не только «традиционными» фейками, составляющими предмет теории журналистики, но и «кричащими» интернет-заголовками особого типа, функционирующими практически повсеместно в качестве рекламно-гипертекстовых сигналов по отношению к основному медиатексту. Поскольку такие заголовки выступают на веб-странице автономно (для знакомства с основным текстом требуется переход по ссылке или «цепочке» ссылок), то их можно рассматривать в качестве сообщений с самостоятельным текстовым статусом. По Е.А. Сазонову, они попадают в категорию квазисенсаций, мы же будем называть их псев- 
досенсациями («псевдо-» представляется более предпочтительным, нежели «квази-», в силу большей употребительности и благозвучности этой приставки, ср.: псевдособытие, псевдореальность, псевдокультура). Эти сообщения создаются исключительно с опорой на исходный текст, и порождаемая таким образом псевдосенсация представляет собой компрессионный лингвистический «эрзац» текста, сконструированный посредством логико-семантических приемов и с учетом когнитивных механизмов восприятия информации реципиентом. Ниже рассмотрены такие приемы и механизмы.

\section{Материал и методы исследования}

В представленной работе мы продолжаем серию исследований, методология которых была разработана нами ранее (см.: [Негрышев, 2004, с. 27-56; 2006]). Она базируется на известной в дискурсологии концепции Т. ван Дейка [Дейк, 1989, с. 228-267] (см. также: [Лазарева, 1989, с. 7-16]) и типологии семантических преобразований Ю.И. Левина, представленной в его статье «О семиотике искажения истины» [Левин, 1998]. Модель отношений в системе «заголовок $\leftrightarrow$ текст» была обоснована нами на материале кратких новостных заметок печатной прессы; тексты Интернета, который на тот момент только завоевывал массовое коммуникативное пространство, к анализу не привлекались. Сегодня нет недостатка в материале, позволяющем восполнить этот пробел.

Предварительно заметим, что основное отличие заголовка на веб-странице от «обычного» заголовка заключается в его анонсовогипертекстовом характере: интернет-заголовок выступает чаще всего как автономный «мини-текст» с рекламной функцией, суть которой заключается в мотивации реципиента к переходу по гиперссылке на страницу с основным текстом. В медиалингвистике такие заголовочные формы получили наименование новостного анонса [Ковальчукова, 2008], в последнее время из области маркетинга заимствован также термин кликбейт [Николаева, 2017], под которым понимается заголовочный комплекс, включающий в себя помимо текста также графические и/или мульти- медийные элементы и функционирующий в качестве «приманки» для потенциального посетителя сайта-заказчика.

Итак, нашей задачей было выявление логико-семантических преобразований (трансформаций) текстовой информации в заголовке. За исходный «критерий качества», то есть за «нулевую трансформацию» мы приняли ситуацию изоморфизма пропозициональной структуры текста и заголовка: базовая пропозиция текста в своих основных компонентах и отношениях между ними воспроизводится в заголовке. Нарушение указанного изоморфизма - искажение информации - мы рассмотрели на двух уровнях: пропозициональное выдвижение и логико-семантические трансформациии.

На I уровне были выделены способы выдвижения пропозиции («топика» в терминологии Т. ван Дейка) в заголовок: общзй топик (далее - ОТ) - выдвигается основная пропозиция; частный топик (далее - ЧТ) выдвигается одна из деталей события; комбинированный топик (далее - КТ) - объединяются фрагменты основной и/или детализирующей пропозиций [Негрышев, 2006, c. 100-102].

Пропозиции могут либо извлекаться в «чистом виде» - тогда заголовочное конструирование остается в пределах первого уровня, либо перемещаться на II уровень, где топик подвергается дальнейшим логико-семантическим трансформациям. Из выделенных ранее двух типов таких трансформаций - компонентных (формальных) и семантических (модальных) - на данный момент представляется более актуальным рассмотрение только компонентных трансформаций, поскольку именно им принадлежит ведущая роль в подмене текстового содержания шокирующе броским новостным заголовком. Семантические же трансформации представляют собой, по сути, когнитивно-семантические операции, осуществляемые читателем в процессе восприятия уже «готового» заголовка, «запрограммированного» автором на определенное прочтение. К компонентным трансформациям относятся субституциия, элиминация, позиционирование и компликацчия [Негрышев, 2006, с. 103-107]. Что же касается семантических трансформаций, то 


\section{РАЗВИТИЕ И ФУНКЦИОНИРОВАНИЕ РУССКОГО ЯЗЫКА}

здесь мы ограничимся лишь выявлением наиболее общих когнитивно-прагматических механизмов, обеспечивающих воздействующий потенциал сконструированного заголовка, а именно охарактеризуем механизм формирования ложной пресуппозиции посредством апелляции к когнитивному и дискурсивному тезаурусам пользователя. Под когнитивным тезаурусом мы понимаем знания реципиента о ключевых объектах и персоналиях медиапространства и их фоновых конвенционально-оценочных характеристиках (например, В.В. Путин - Президент Российской Федерации, А. Макаревич - известный музыкант и т. п.). Дискурсивный тезаурус включает в себя знание реципиентом фреймов и сценариев подачи информации в том или ином субдискурсе СМИ, то есть своего рода коммуникативные ожидания от соответствующего типа текста. Например, в новостном дискурсе событие «по умолчанию» воспринимается как актуальное - происходящее «здесь» (в нашей стране) и «сейчас» (во временном интервале одного дня), значимое - касающееся «важных» персон и/или затрагивающее интересы многих людей, «новое» - предполагающее изменение положения дел и т. д.

Материал исследования составили заголовки, отобранные методом сплошной выборки на российских интернет-порталах информационно-новостной направленности за 2016-2019 годы. Рассматривались только заголовки-гиперссылки, размещенные, как правило, в составе кликбейта в так называемом «тизерном» блоке баннерного пространства интернет-страницы. Проходя далее по гиперссылке(ам) до конечного текста, являющегося исходным для заголовочного конструирования, мы сопоставляли базовую пропозицию текста на предмет изоморфизма с заголовочной номинацией. Число заголовков, включенных в исследовательскую базу, составило около 1000 единиц.

\section{Результаты и обсуждение}

Преобразования I уровня. При всей эпатажности псевдосенсационных заголовков приходится констатировать, что в абсолютном большинстве случаев пропозициональное выдвижение в них осуществляется по моде- ли ОТ: в заголовок выносится основная пропозиция текста, подвергающаяся затем логико-семантическим трансформациям II уровня. Исключения редки, и они в основном относятся к типу ЧТ, например:

(1) Вот что было написано в предсмертной записке Даны Борисовой (ognyvo.ru. 13.12.2016).

В тексте речь идет о продолжении скандала вокруг романа Даны Борисовой и Александра Морозова, а именно о том, что она подала заявление в Следственный комитет, обвиняя своего бывшего возлюбленного в клевете, угрозах и доведении до самоубийства. «Предсмертная записка» в микроблоге Борисовой выступает в сообщении в качестве детали повествования (ЧТ), самой существенной в ряду обвинений, но не являющейся основной в иерархии топиков текста. Приведем еще один пример, где также эксплуатируется тематика смерти, весьма популярная на тизерных интернет-страницах:

(2) Леонид Якубович скончался прошедшей ночью в подъезде собственного дома (pressnews.xyz. 18.11.2017).

Основное содержание заметки сосредоточено вокруг тезиса о том, что пользователи Интернета привыкли к таким материалам, в которых заживо хоронят разных знаменитых людей. В тексте упоминаются Алла Пугачева, дочь В.В. Путина и наиболее подробно разбираются истоки инсинуаций по поводу «очередной» якобы смерти Л. Якубовича. Именно этот ЧТ текста вынесен в заголовок и, не будучи взятым в кавычки, сам представляет собой типичный пример такого рода инсинуаций.

Преобразования II уровня. Именно на эти преобразования приходится основная нагрузка в создании псевдоэффекта сенсационности заголовка. Из четырех выделенных ранее компонентных трансформаций (субституции, элиминации, позиционирования, компликации) мы вынуждены исключить позиционирование - перестановку компонентов, поскольку в качестве конструктивного механизма в системе «заголовок $\leftrightarrow$ текст» в Интернете эта трансформация не используется. Позиционирование может выступать как синтакси- 
ческая инверсия для коммуникативного выделения какого-либо элемента пропозиции, но лингвостилистическая экспрессия не входит в предмет нашего рассмотрения. Начнем с наиболее распространенного, если не сказать «базового» типа компонентных трансформаций, - элиминации.

1. Элиминация («аннулирующее преобразование» по Ю.И. Левину) состоит в исключении из заголовка одного или более компонентов текстовой пропозиции. «Кликабельность» заголовка возникает за счет недосказанности - читателя мотивируют к переходу по ссылке ради «разгадки» заголовочной «интриги». Материал российских тизерных сетей позволяет выделить несколько разновидностей данной трансформации.

1.1. Именная элиминация. Чаще всего элиминации данного типа подвергаются номинации, относящиеся к знаменитостям. Например:

(3) Дочь рассказала о смерти Макаревича (vestivdetails.ru. 10.01.2018).

В этом заголовке элиминирована часть имени собственного и его дескрипция - Алексей Макаревич - экс-гитарист группь «Воскресение». Очевидно, что при восприятии такого заголовка в когнитивном тезаурусе читателя актуализируется компонент «Андрей Макаревич - лидер группы “Машина времени”», а в дискурсивном - компонент «значимости» лица, о котором сообщается. При такой ложной актуализации «новость» о якобы смерти известного музыканта звучит куда более сенсационно, нежели какая бы то ни было информация о малоизвестном экс-гитаристе «Воскресения». Аналогичный пример:

(4) Садальский сообщил о смерти Васильевой (mir-press.com. 01.03.2018).

При упоминании этой фамилии без имени у читателя возникает ложная идентификация с Татьяной Васильевой - давним сценическим партнером и другом С. Садальского, отношения которых многократно становились объектом внимания СМИ. Между тем речь идет о смерти поэтессы Ларисы Васильевой, не столь известной широкой публике и никогда медийно не «ассоциированной» с Садальским. Приведем еще один пример ложной актуализации компонентов когнитивного и дискурсивного тезаурусов пользователя посредством элиминации:

(5) Амаяк Акопян застрелен в Армении (riafan.ru. 28.05.2018).

В статье под заголовком (5) речь идет о капитане армянской армии, не имеющем ничего общего со знаменитым иллюзионистом, кроме имени и фамилии.

1.2. Атрибутивная элиминация-опущение атрибута при пропозиционально значимом референте, как, например, в «громком» заголовке:

(6) Между Россией и США началась полноценная война (content.directadvert.ru. 05.08.2017).

На самом деле речь идет об информационной войне, сообщение о которой едва ли можно считать сенсационным в контексте отношений между Россией и США. Другой пример атрибутивной элиминации:

(7) В Кремле прокомментировали отставку Матвиенко (rusplt.ru. 31.08.2018).

В исходном материале речь идет о возможной отставке Матвиенко, слухи о которой опроверг пресс-секретарь Президента Д. Песков (iz.ru. 30.08.2018).

Элиминации может подвергаться и несогласованное постпозитивное определение. Так, российскую интернет-общественность на протяжении нескольких лет активно «готовили» к потенциально сенсационному научномедицинскому событию - пересадке головы человека. Например:

(8) Голову пересадили: операция успешна! (ognyvo.ru. 03.12.2016).

Этот заголовок с переходом по гиперссылке на Операция по пересадке головы случилась: все прошло успешно (lifesmi.com. 03.12.2016) апеллирует именно к такому ожиданию в когнитивном и дискурсивном тезаурусах пользователя. О том, что речь идет 


\section{РАЗВИТИЕ И ФУНКЦИОНИРОВАНИЕ РУССКОГО ЯЗЫКА}

лишь о пробных операчиях на мыши и собаке, можно выяснить только прочитав по третьему переходу основной материал на сайте lifesmi.com.

\section{3. Предикативная элиминация} заключается в усечении составного сказуемого либо значимого элемента предикативной группы. Например:

(9) «Порошенко обречен». Вассерман озвучил мрачный прогноз для президента (smi2.ru. 09.11.2016).

Первое предложение сконструировано здесь путем усечения составного глагольного сказуемого в исходном заголовке Вассерман: Пороченко обречен реагировать на любой выпад Савченко (nsn.fm. 31.10.2016). Другой пример:

(10) Путин высказался о возможности отдать Курилы (lenta.ru. 22.06.2019).

Здесь введение в заблуждение построено на игре с сочетаемостью глагола высказаться. Как известно, высказаться можно: 1) о чемлибо, то есть выразить мнение по какомулибо вопросу; 2) за или против чего-либо (Ушаков, с. 88). При употреблении глагола в первом значении, если речь идет о кратком высказывании, обязательно наличие обстоятельственного распространителя в предикативной группе, например, высказался сочувственно, положительно / отрицательно и т. п. Без такого распространителя вариативность интерпретации высказывания возрастает, а в данном примере дополнительно усиливается за счет зависимого от глагола существительного с семантикой модальности. Приведенный заголовок можно понять и как *Путин высказал свое мнение относительно возможсности / невозможсности отдать Куриль, и как *Путин высказался о существующей возможности отдать Kуриль. При сопоставлении с текстом становится очевидным, что адекватным содержанию текста заголовком был бы *Путин высказался негативно о возможности отдать Kуриль, из чего следует, что элиминация именно оценочного компонента предикативной группы создает эффект сенсационности «позиции» Президента по Курилам.
1.4. Темпоральная элиминация - усечение показателя времени - встречается в двух разновидностях: ретроспективная темпоральная элиминация и проспективная темпоральная элиминация. Ретроспективная темпоральная элиминация позволяет «извлекать» из истории факты, давно потерявшие свою актуальность, особенно если они связаны с жизнью известных медиаперсон. Например:

(11) Пугачева в ярости выкинула вещи любовника из квартиры (dni.ru. 06.09.2017).

В заголовке элиминировано обстоятельство времени в тот момент, а именно - в период любовного романа Аллы Пугачевой и Владимира Кузьмина, то есть около 30 лет назад. Подобный пример:

(12) «Путин вышел, хлопнув дверью»: раскрыта тайна торжественного обеда в Гамбурге (newinform.com. 14.08.2017).

В заголовке не уточняется, что произошло это 8 1994 году на обеде в Гамбурге в бытность В. Путина вице-мэром Санкт-Петербурга.

Проспективная темпоральная элиминация основана на обыгрывании прогнозируемых событий путем смещения их сроков в сторону актуального настоящего. Например:

(13) ЕГЭ по иностранному языку станет обязательным (mirnov.ru. 31.05.2017).

В заголовке нет показателей времени, поэтому в дискурсивном тезаурусе пользователя «по умолчанию» актуализируется «обозримое будущее» - текущий либо ближайший учебный год. Однако по прочтении текста выясняется, что Министерство образования планирует это сделать только к 2022 году. Подобный пример:

(14) В России могут полностью отменить пенсии (directadvert.ru. 30.08.2017).

В информационном материале речь идет лишь о неофициальном прогнозе, сделанном ректором РАНХиГС Владимиром Мау в комментарии к предложению Минэкономразвития изменить порядок налогообложения. Он заявил, 
что уже через 20 лет пенсии могут быть отменены.

Во всех случаях темпоральной элиминации манипуляция смыслом осуществляется, как видим, за счет подмены в сфере дискурсивного тезауруса пользователя. Как уже отмечалось, при восприятии информации в новостном дискурсе по умолчанию активируются пространственно-временные координаты «здесь и сейчас». Искусственная актуализация заведомо устаревшего либо слишком далекого «события» обеспечивается посредством исключения показателя актуальности, чем и достигается видимость сенсации.

1.5. Локальная элиминация. Усечение показателей места встречается реже, однако, как и в случае темпоральной элиминации, здесь наблюдается апелляция к дискурсивному стереотипу восприятия новостной информации в качестве актуальной «здесь и сейчас». Например:

(15) Армия не подчинилась президенту (rbc.ru. 09.09.2017).

При отсутствии локального дейксиса в заголовке для российского интернет-пользователя президент будет означать «В.В. Путин», а армия - «российские вооруженные силы». В действительности же речь идет о Национальной армии Молдавии, руководство которой вопреки запрету президента И. Додона направило контингент в составе 57 военных на учения HATO Rapid Trident 2017. Другой пример:

(16) Депутат выпал из окна во время драки в парламенте (news.mail.ru. 08.10.2016).

В заголовке элиминированы определения, содержащие отсылки к месту действия и государственной принадлежности «героя» новости (европейский парламент, британский denymam).

1.6. Элиминация упоминания источника. Указание источника информации является, как известно, обязательным компонентом качественной новости, хотя для заголовка этот компонент не обязателен по причине краткости формулировки. Следовательно, дискурсивный тезаурус реципиента не включает в себя ожидание от заголовка информации об источнике информации, чем и пользуются «конструкторы» псевдосенсаций, придавая видимость факта субъективным высказываниям-мнениям отдельных персон. Например:

(17) Россия не построит мост в Крым через Керченский пролив (lentainform.com. 16.08.2017).

В заголовок вынесено мнение министра юстиции Украины Павла Петренко, о чем сообщалось в исходном материале под более достоверным заголовком:

(18) Россия не построит мост в Крым через Керченский пролив - Минюст Украины (polit.info. 04.08.2017).

Приведем еще один пример на украинскую тематику:

(19) Порошенко отправили под домашний арест (media-personal.com. 07.11.2017).

Кликбейт отсылает к «версии» одного сетевого «аналитика» о якобы произошедшем в Киеве перевороте, о котором, по словам блогера, свидетельствует ряд на первый взгляд не связанных друг с другом событий. Это мнение, пересказанное на utro.ru/ politics 03.11.2017, было подхвачено тизерными сетями, превратившись при этом в «новостной факт» за счет элиминации источника информации.

1.7. Усечение цитаты. Усеченное цитирование традиционно относится к манипулятивным приемам, приводящим к существенному искажению смысла цитируемого высказывания (см.: [Варченко, 2007, с. 34-36, 83]). Например:

(20) Лукашенко потребовал сделать белорусских детей «одинаковыми» (km.ru. 15.08.2017).

В заголовке процитировано только одно слово из высказывания А. Лукашенко и опущен контекст, проясняющий его смысл. На самом деле президент Белоруссии в ходе рабочей встречи с чиновниками правительства перед началом учебного года уделил особое внимание школьным базарам и сделал акиент на малоимущих семьях. Слово одинаковые 


\section{РАЗВИТИЕ И ФУНКЦИОНИРОВАНИЕ РУССКОГО ЯЗЫКА}

Лукашенко употребил не в смысле некоей «тоталитарной унификации» детей, а в том плане, что 1 сентября все дети должны быть одеты достойно и чтобы не выделялись дети из семей, которые не так богатьи сегодня.

2. Субституция означает подмену значимых компонентов текстовой пропозиции, то есть замещение в заголовке слов и/или словосочетаний, содержащихся в тексте. Субституция функционирует в области именного референта и в сфере предиката.

2.1. Именная субституция практически всегда сопровождает рассмотренную выше именную и нередко атрибутивную элиминацию (см. п. 1.1 и 1.2), поскольку усечение наименования, например, лица, ведет не к устранению упоминания о нем, а к подмене: неизвестное (в тексте) подменяется якобы известным (в заголовке). Однако именная субституция встречается и в «чистом виде», в частности в материалах, посвященных персоналиям, для которых, видимо, невозможно подобрать «двойника» из числа «топовых» медиаперсон, способных усилить «кликабельность» заголовка. В таких случаях текстовый референт в заголовке заменяется на оценочную дескрипцию, с одной стороны, создающую эффект неопределенности, а с другой - содержащую намек на широкую известность упоминаемого лица. Например:

(21) Скончалась всенародно любимая актриca (dni.ru. 07.10.2017).

Здесь под всенародно любимой подразумевается франиузская актриса и писательница Анна Вяземски. Едва ли ее имя и фамилия о чем-то говорят «всему народу России», однако компонент «значимости события», входящий в дискурсивный тезаурус реципиента новостей, активируется номинацией всенародно любимая: замена имени собственного на оценочную дескрипцию используется для придания событию большей новостной ценности.

Именная субституция может иметь и опосредованный характер, когда оценочная дескрипция не заменяет наименование самого «немедийного» субъекта, а сопровождает обозначение связанного с ним события, например:
(22) В правительстве РФ произошла крупная отставка (news.mail.ru/society. 24.11.2018).

Крупной отставкой назван уход с должности заместителя министра энергетики Вячеслава Кравченко (rbc.ru/business. 15.11.2018).

Особым случаем именной субституции можно считать метафорические и метонимические номинации, не заключенные, как это следовало бы ожидать, в кавычки:

(23) Песков прокомментировал запуск токшоус Путиным в роли ведущего (mail.ru. 23.05.2019).

В информации под этим заголовком сообщается о британском шоу с 3D-ведущим в виде Путина. Замена 3D-ведущим в виде Путина на Путина, при которой метонимическое понятие не заключено в кавычки, сопровождается атрибутивно-локальной элиминацией (британского), усиливающей псевдосенсационность кликбейта за счет апелляции к дискурсивному тезаурусу реципиента.

2.2. Предикативная субституция встречается в двух основных разновидностях в виде полной подмены предикативной группы и путем манипуляций с глаголами говорения.

Полная подмена предикативной группы связана с переосмыслением всей ситуации. Например:

(24) Макрон отказался от престарелой жены (rustoria-topnews.ru. 08.08.2017).

В заголовке переосмыслен тот факт, что президент Франции Э. Макрон отказался узаконить статус супруги президента, предусматривавший выделение средств на расходы супруги главы государства. Такое весьма «вольное» преобразование предикативной группы объяснимо только намерением мотивировать читателя к переходу по гиперссылке. Приведем еще один пример конструирования такого типа:

(25) Как на Украине прошли похороны Олега Царева (infox.ru. 14.08.2018).

В заголовке под похоронами подразумеваются очередные слухи о смерти политика 
Новороссии, которые периодически тиражируются в украинских СМИ.

На тизерных сайтах встречаются и особенно грубые семантические подмены, когда предикаты заголовка и текста связывает лишь принадлежность к одной тематической группе, но лексические значения глаголов не совпадают:

(26) Суд вынес приговор Улюкаеву (ex.24smi.info. 21.07.2017) $\leftarrow$ Суд продлил домашний арест Улюкаева (glavnoe.io/news. 13.07.2017).

Замена продлить арест на вынести приговор приводит к полной дезинформации пользователя за счет эксплуатации дискурсивного ожидания «значимости события» - третье на тот момент продление ареста экс-министра значительно уступает по «сенсационности» вынесению приговора.

Манипуляции с глаголом говорения всегда связаны с подменами в области морфологической и лексической сочетаемости. Чаще всего манипуляциям подвергаются глаголы высказаться, рассказать, заявить, ответить, потребовать и т. п. Так, глагол заговорить в сочетании с именной группой с предлогом после имеет значения «начать разговаривать (после операции, после аварии, после травмы и т. п.)» либо «возобновить общение (после долгого молчания)».

(27) Билан заговорил после ДТП (lenta.ru. 19.09.2018).

В этом заголовке актуализируется именно первое значение, из которого вытекает ложная пресуппозиция о якобы утрате Д. Биланом речевой способности в результате аварии. В действительности же певец всего лишь высказался об аварии, в которую он попал. Другой пример:

(28) В Кремле рассказали о причастности России к мятежу в Черногории (news.mail.ru. 07.11.2016) $\leftarrow$ Кремль опроверг причастность России к попытке переворота в Черногории (vazhno.info/news. 07.11.2016).

Употребление глагола рассказать вместо опровергнуть приводит к полному изменению смысла события в целях создания эффекта сенсационности.
3. Компликация означает введение в заголовок дополнительных компонентов, не представленных эксплицитно в тексте. Если в случае субституции вымышленный смысл формируется из имеющихся в тексте компонентов, то при компликации он полностью привносится извне. Можно выделить три основных ее типа: ссылка на «авторитетное мнение», вымышленная «реакция» на событие, употребление апеллятива. Характеризуя компликацию, мы посчитали излишним приводить конкретные примеры со ссылками как по причине их повсеместной и «ежеминутной» доступности в сети, так и в силу «натуралистичности» и абсолютной абсурдности их содержания.

3.1. Ссылка на «авторитетное мнение». Это может быть обезличенное «мнение» профессионалов в какой-либо области: ученые умоляют, медики в шоке, онкологи сообщили, кардиологи предупреждают, диетологи советуют, личный совет уроло$2 a$, указание на вымышленный должностной статус: Главный врач (диетолог, ортопед и т. п.) России (Москвы, Владимира и т. п.), упоминание реальных имен собственных, носители которых, однако, зачастую не имеют отношения к самой новости: Рошаль, Дикуль, Мальшева и др.

3.2. Вымышленная "реакция" на событие: Все просто ахнули от..., Россияне не смогли сдержать слез, узнав.., Врачи побледнели, когда..., Путин рухнул, как подкошенный, когда... и т. п.

3.3. Употребление апеллятивов - парцеллированных экспрессивных компонентов, направленных на привлечение внимания читателя к заголовку:

Важно! Ужас! Шок! Вот это новость! Будете поражень! Присядьте... Такого не ожидали? Москва в панике! и т. п.

Все выделенные трансформации тесно взаимосвязаны и нередко наблюдается их сочетание в рамках одного заголовка. Так, субституция, как было показано выше, неотделима от элиминации и может сопровождаться при этом компликацией на пресуппозитивном уровне. Например:

(29) После инсульта Волочкова покупает инвалидное кресло (media-personal.com. 07.10.2017). 


\section{РАЗВИТИЕ И ФУНКЦИОНИРОВАНИЕ РУССКОГО ЯЗЫКА}

В заголовке элиминировано упоминание субъекта (отиа балерины), перенесшего инсульт и нуждающегося в инвалидном кресле. Тем самым происходит как субститутивная подмена референта (покупает в заголовке «по умолчанию» прочитывается как «покупает себе»), так и компликативное достраивание ситуации на уровне пресуппозиции (*Boлочкова перенесла инсульт), таким образом, в заголовке используются все три описанных выше трансформации. Другой пример:

(30) Смерть застала Наташу Королеву на курорте (week-news24.ru. 16.02.2019).

Под этим заголовком размещена информация о смерти бабушки певицы. Исходная текстовая пропозиция реконструируется как *Известие о смерти бабушки застало Наташу Королеву на курорте, то есть использована двойная элиминация - опущены компоненты известие и бабушка. При этом существенно трансформируется семантика предиката: имеет место предикативная субституция (идиоматическое выражение смерть застала кого-либо где-либо означает факт смерти самого субъекта, о котором идет речь, в то время как известие о чем-либо может быть адресовано только живому человеку).

\section{Заключение}

Таким образом, для лингвистического рассмотрения псевдосенсации сначала необходимо отделить «сенсацию-сообщение» от «сенсациисобытия» и «сенсации-впечатления», а затем сосредоточиться на тех «сенсациях-сообщениях», которые «замкнуты» на лингвистический материал, то есть являются производными от других текстовых сообщений. Такого рода псевдосенсации представлены в Интернете в форме заголовков-гиперссылок, сконструированных на основе исходного текста посредством логико-семантических трансформаций. Набор моделей такого конструирования ограничен и укладывается в традиционную триаду фальсификации информации: умолчание (элиминация), подмена (субституция) и домысел (компликация). Описанные в статье трансформации позволяют превратить в псевдосенсацию медиатекст практически любого содержания вне зависимости от его жанровой принадлежности. При этом все логико-семантические трансформации осуществляются с опорой на те компоненты дискурсивного и когнитивного тезаурусов реципиента, которые позволяют придать сообщению бо́льшую новостную ценность, чем оно имеет в действительности. Все это провоцирует ложное коммуникативное ожидание, выполняющее роль функционального стимула (триггера) для мотивации пользователя к переходу по гиперссылке. Прагматический характер сетевых псевдосенсаций не являлся предметом нашего рассмотрения, заметим лишь, что их конечная цель - монетизация интернет-портала - предельно ситуативна и непредполагает порождения сколь-либо значимого общественно-медийного резонанса.

\section{СПИСОК ЛИТЕРАТУРЫ}

Варченко В. В., 2007. Цитатная речь в медиа-тексте. М. : Изд-во ЛКИ. 240 с.

Дейк ван Т. А., 1989. Язык. Познание. Коммуникация / сост. В. В. Петрова. М. : Прогресс. 312 с.

Ильченко С. Н., 2018. Фейк как антиисточник информации: риск для профессиональных стандартов журналистики // Гуманитарный вектор. T. 13, № 5. C. 70-76. DOI: 10.21209/1996-78532018-13-5-70-76.

Иссерс О. С., 2014. Медиафейки: между правдой и мистификацией // Коммуникативные исследования. № 2. С. 112-123.

Ковальчукова М. А., 2008. Анонс как речевой жанр (на материале интернет-дискурса) // Вестник Челябин. гос. ун-та. № 30. С. 54-57.

Лазарева Э. А., 1989. Заголовок в газете. Свердловск : Изд-во Урал. ун-та. $96 \mathrm{c.}$

Левин Ю. И., 1998. О семиотике искажения истины // Левин Ю. И. Избранные труды. Поэтика. Семиотика. М. : Яз. рус. культуры. С. 594-605.

Негрышев А. А., 2004. Механизмы медиации в новостийном дискурсе. Владимир : ВФ НГЛУ им. Н.А. Добролюбова. 116 с.

Негрышев А. А., 2006. Прагматика новостного газетного заголовка: механизмы преобразования информации в системе заголовок $\leftrightarrow$ текст // Вестник Московского университета. Серия 9, Филология. № 1. С. 97-109.

Николаева А. В., 2017. Кликбейт: к определению понятия // Актуальные проблемы стилистики. № 3. С. 146-151.

Сазонов Е. А., 2004. «Желтая» пресса в контексте развития печати XX века (социокультурный аспект) : автореф. дис. ... канд. филол. наук. Воронеж. 20 c. 
Тертычный А. А., 2003. Сенсация - выстрел без промаха // Журналист. № 10. С. 76-78.

\section{СЛОВАРЬ}

Ушаков - Ушаков Д. Н. Толковый словарь современного русского языка. М. : Аделант, 2014. $800 \mathrm{c}$.

\section{REFERENCES}

Varchenko V.V., 2007. Tsitatnaya rech v media-tekste [Citation in Media Texts]. Moscow, Izd-vo LKI. $240 \mathrm{p}$.

Dijk van T.A., 1989. Yazyk. Poznanie. Kommunikatsiya [Language. Cognition. Communication]. Moscow, Progress Publ. 312 p.

Il'chenko S.N., 2018. Feyk kak antiistochnik informatsii: risk dlya professionalnykh standartov zhurnalistiki [Fake as an Anti-Source of Information: A Risk for Professional Standards of Journalism]. Gumanitarnyy vector [Humanitarian Vector], vol. 13, no. 5, pp. 70-76. DOI: 10.21209/1996-7853-2018-13-5-70-76.

Issers O.S., 2014. Mediafeyki: mezhdu pravdoy i mistifikatsiey [Mediafake: Between Truth and Hoax]. Kommunikativnye issledovaniya [Communication Studies], no. 2, pp. 112-123.

Kovalchukova M.A., 2008. Anons kak rechevoy zhanr (na materiale internet-diskursa) [Announce as a Speech Genre (Based on Internet Discourse)]. Vestnik Chelyabinskogo gosudarstvennogo universiteta [Bulletin of Chelyabinsk State University], no. 30. pp. 54-57.

Lazareva E.A., 1989. Zagolovokv gazete [Headline in a Newspaper]. Sverdlovsk, Izd-vo Uralskogo universiteta. $96 \mathrm{p}$.
Levin Yu.I., 1998. O semiotike iskazheniya istiny [On the Semiotics of Truth Perversion]. Levin Yu.I. Izbrannye trudy. Poetika. Semiotika [Selected Works. Poetics. Semiotics]. Moscow, Yazyki russkoy kultury Publ., pp. 594-605.

Negryshev A.A., 2004. Mekhanizmy mediatsii v novostiynom diskurse [Mechanisms of Mediation in News Discourse]. Vladimir, VF NGLU im. N. A. Dobrolyubova. 116 p.

Negryshev A.A., 2006. Pragmatika novostnogo gazetnogo zagolovka: mekhanizmy preobrazovaniya informatsii v sisteme zagolovok $\leftrightarrow$ tekst [Pragmatics of the Newspaper News Headline: Mechanisms of Information Transforming in the System Headline $\leftrightarrow$ Text]. Vestnik Moskovskogo universiteta. Seriya 9. Filologiya [Moscow State University Bulletin. Series 9. Philology], no. 1, pp. 97-109.

Nikolaeva A.V., 2017. Klikbeyt: k opredeleniyu ponyatiya [Clickbait: Search for a Definition]. Aktualnye problemy stilistiki, no. 3, pp. 146-151.

Sazonov E.A., 2004. "Zheltaya» pressa v kontekste razvitiya pechati XX veka (sotsiokulturnyy aspekt): avtoref. dis. ... kand. filol. nauk ["Yellow" Press in the Context of the Development of the Press of the $20^{\text {th }}$ Century (Sociocultural Aspect). Cand. philol. sci. abs. diss.]. Voronezh. $20 \mathrm{p}$.

Tertychnyy A.A., 2003. Sensatsiya - vystrel bez promakha [Sensation - Shot without a Miss]. Zhurnalist, no. 10, pp. 76-78.

\section{DICTIONARY}

Ushakov D.N. Tolkovyy slovar sovremennogo russkogo yazyka [Explanatory Dictionary of Contemporary Russian]. Moscow, Adelant Publ., 2014. 800 p.

\section{Information About the Author}

Andrej A. Negryshev, Candidate of Sciences (Philology), Associate Professor, Department of German and French, Vladimir State University named after Alexander and Nikolay Stoletovs, Prosp. Stroiteley, 11a, 600024 Vladimir, Russia, negryshev@inbox.ru, https://orcid.org/0000-0002-8251-3605

\section{Информация об авторе}

Андрей Александрович Негрышев, кандидат филологических наук, доцент кафедры немецкого и французского языков, Владимирский государственный университет им. А.Г. и Н.Г. Столетовых, просп. Строителей, $11 \mathrm{a}, 600024$ г. Владимир, Россия, negryshev@inbox.ru, https://orcid.org/0000-0002-8251-3605 